Maurer School of Law: Indiana University

Digital Repository @ Maurer Law

2014

\title{
Digging Deeper into Hardin's Pasture: The Complex Institutional Structure of "The Tragedy of the Commons"
}

Daniel H. Cole

Indiana University Maurer School of Law, dancole@indiana.edu

Graham Epstein

Indiana University - Bloomington

Michael D. McGinnis

Indiana University - Bloomington

Follow this and additional works at: https://www.repository.law.indiana.edu/facpub

Part of the Demography, Population, and Ecology Commons, Natural Resource Economics Commons, and the Political Economy Commons

\section{Recommended Citation}

Cole, Daniel H.; Epstein, Graham; and McGinnis, Michael D., "Digging Deeper into Hardin's Pasture: The Complex Institutional Structure of "The Tragedy of the Commons"'" (2014). Articles by Maurer Faculty.

1675.

https://www.repository.law.indiana.edu/facpub/1675

This Article is brought to you for free and open access by the Faculty Scholarship at Digital Repository @ Maurer Law. It has been accepted for inclusion in Articles by Maurer Faculty by an authorized administrator of Digital Repository @ Maurer Law. For more information, please contact rvaughan@indiana.edu. 


\title{
Digging deeper into Hardin's pasture: the complex institutional structure of 'the tragedy of the commons'
}

\author{
DANIEL H. COLE* \\ Maurer School of Law and School of Public and Environmental Affairs, Indiana University, Bloomington, IN 47405, \\ USA \\ Vincent and Elinor Ostrom Workshop in Political Theory and Policy Analysis, Indiana University, Bloomington, \\ IN 47408, USA

\section{GRAHAM EPSTEIN*} \\ Department of Political Science, School of Public and Environmental Affairs, Indiana University, Bloomington, \\ IN 47405, USA \\ Vincent and Elinor Ostrom Workshop in Political Theory and Policy Analysis, Indiana University, Bloomington, \\ IN 47408, USA \\ MICHAEL D. MCGINNIS *** \\ Department of Political Science, School of Public and Environmental Affairs, Indiana University, Bloomington, \\ IN 47405, USA \\ Vincent and Elinor Ostrom Workshop in Political Theory and Policy Analysis, Indiana University, Bloomington, \\ IN 47408, USA
}

\begin{abstract}
A revised application of Ostrom's (Ostrom, 2007) Social-Ecological System (SES) framework to Hardin's 'tragedy of the commons' (Hardin, G. (1968), Science, 162(3859): 1243-1248) demonstrates that its institutional structure is more complex than either Hardin or Ostrom had imagined. The 'tragedy' arises from several interacting resources and institutions. If the grass on the pasture was not subject to appropriation, the cattle were not privately owned, or property- and contract-enforcement institutions supporting market exchange were absent, then the 'tragedy of the commons' would not have arisen regardless of the open-access pasture. This paper highlights the utility of the SES framework and the care required to apply it precisely to specific social-ecological situations.
\end{abstract}

\section{Introduction}

Hardin's (1968) 'tragedy of the commons' remains a uniquely powerful and controversial contribution to both social and natural sciences. The classic allegory, which warns of the dangers associated with situations that generate private benefits and shared costs, is an integral part of the curricula in multiple disciplines. Its sustained influence is a product of both its ability to successfully

\footnotetext{
*Email: dancole@indiana.edu

**Email: gepstein@indiana.edu

***Email: mcginnis@indiana.edu
} 
predict resource collapse (Brook et al., 2003; Edmondson et al., 1956; Ludwig et al., 1993; Myers et al., 1997) and its myopic failure to consider the possibility that groups of resource users might recognize the dangers of overexploitation and successfully develop self-organized systems of commonproperty governance (Baland and Platteau, 1996; Ostrom, 1990; Wade, 1994). The evidence concerning the viability of these small-scale common-property systems is by now irrefutable (Chhatre and Agrawal, 2009; Cox et al., 2010; Gutiérrez et al., 2011), although their success ultimately depends upon the fit between common-property institutions and the complex social and ecological environment in which they operate (Acheson, 2006; Feeny et al., 1990).

This paper expands on the issue of institutional fit in the context of Hardin's Herder Problem (as it is known among game theorists, e.g., Cole and Grossman, 2010) to show that destruction of the open-access pasture is not a function of a lack of institutions but necessarily depends upon the interactions of various rules-in-use that together generate incentives to overuse. ${ }^{1}$ Failure to recognize the role of these institutional interactions in the Herder Problem suggests that some institutions are so entrenched and taken for granted that even accomplished analysts fail to diagnose the problem accurately. Moreover, inaccurate diagnoses can lead to the deployment of ineffective policy responses that fail to grapple with the complex, often opaque matrix of rules, norms, customs, and conventions within which social and environmental problems arise.

To better illuminate that matrix, we employ the Social-Ecological System (SES) framework (Ostrom, 2007, 2009; Ostrom and Cox, 2010), an analytical tool that aims to systematize data collection and integrate knowledge to understand how a diverse assortment of social-ecological attributes and their interactions affects the sustainability of social-ecological systems. The framework has demonstrated its analytic utility through application to a wide range of environmental problems (Ban et al. 2013; Basurto and Ostrom, 2009; Blanco, 2011; Cinner et al., 2012; Fleischman et al., 2010; Gutiérrez et al., 2011).

Notwithstanding its contributions and general acceptance by diverse scholars, the SES framework is a complex tool that can confront an analyst with the seemingly endless task of identifying the entire range of relevant and potentially important social, ecological, and institutional attributes of a social-ecological system. Although a complete account of all these factors is generally unattainable, policy-relevant theoretical explanations must attend to all categories of the factors that substantially structure interactions and affect outcomes in these systems. Some of the institutions that give rise to particular patterns of behavior may not appear immediately obvious, and identifying these hidden but still

1 Cole and Grossman (2010) argue that the Herder Problem is more in the nature of an Assurance Game than a Prisoners' Dilemma, but the outcome of the game may still resemble that of a Prisoners' Dilemma depending on levels of trust, communication, etc. 
effectual institutions requires careful attention to all the categories included in the SES framework.

In her paper introducing the SES framework, Ostrom (2007) argued for the importance of contextual understandings of social-ecological phenomena. Ironically, however, her application of the SES framework to Hardin's 'tragedy of the commons' neglected important attributes of the institutional environment that play understated but significant roles in the demise of the open-access pasture. Like Hardin, Ostrom failed to consider certain institutional conditions that gave rise to the Herder Problem. She treated the ex ante situation in an overly abstract and non-contextual manner. By accepting Hardin's exclusive focus on the absence of private property rights to the pasture, Ostrom overlooked the contributions made by other aspects of the extant institutional context, factors that local groups would have to take into account when they select new institutions in pursuit of 'alternative futures' (V. Ostrom 2008). ${ }^{2}$

This paper shows how a failure to account for preexisting institutional features of the environment can dramatically affect the outcome, leading to either an overexploited or an underexploited open-access pasture. Furthermore, the resulting diagnosis of what is needed to avoid destruction of the common resource may be incomplete and misleading unless the groups involved can understand how their proposed institutional innovations will interplay with the diverse assortment of historical, cultural, and macroinstitutional features of the surrounding environment (Clement, 2010; Larson and Soto, 2008; Pierson, 2000; Ribot et al., 2006).

Section 2 introduces the SES framework and discusses its utility for diagnosing the attributes of a given system that jointly affect social and ecological outcomes. Section 3 then presents Ostrom's (2007) application of the SES framework to Hardin's (1968) Herder Problem, and discusses the problems with her application. Section 4 offers a revised application of the SES framework that draws attention to background institutional factors that include property rights in cattle, the 'rule of capture' applied to the grass on the pasture, and institutions supporting market exchange that generate the individual incentives that drive collective destruction of the pasture. The paper concludes in Section 5 with a discussion on implications of the analysis for both institutional fitness and, more often overlooked, institutional interactions.

\section{The SES framework}

The SES framework (Figure 1) conceptualizes social-ecological systems as partially decomposable systems (Simon, 1962) consisting of six fundamental

2 Ostrom might have been attempting merely to describe what she took to be Hardin's misunderstanding of the range of institutional solutions to the Herder Problem, but she does not explicitly specify which institutions, if any, were already present in that specific situation. 
Figure 1. Basic structure of the SES framework (Ostrom, 2009) as modified by Epstein et al. (2013).

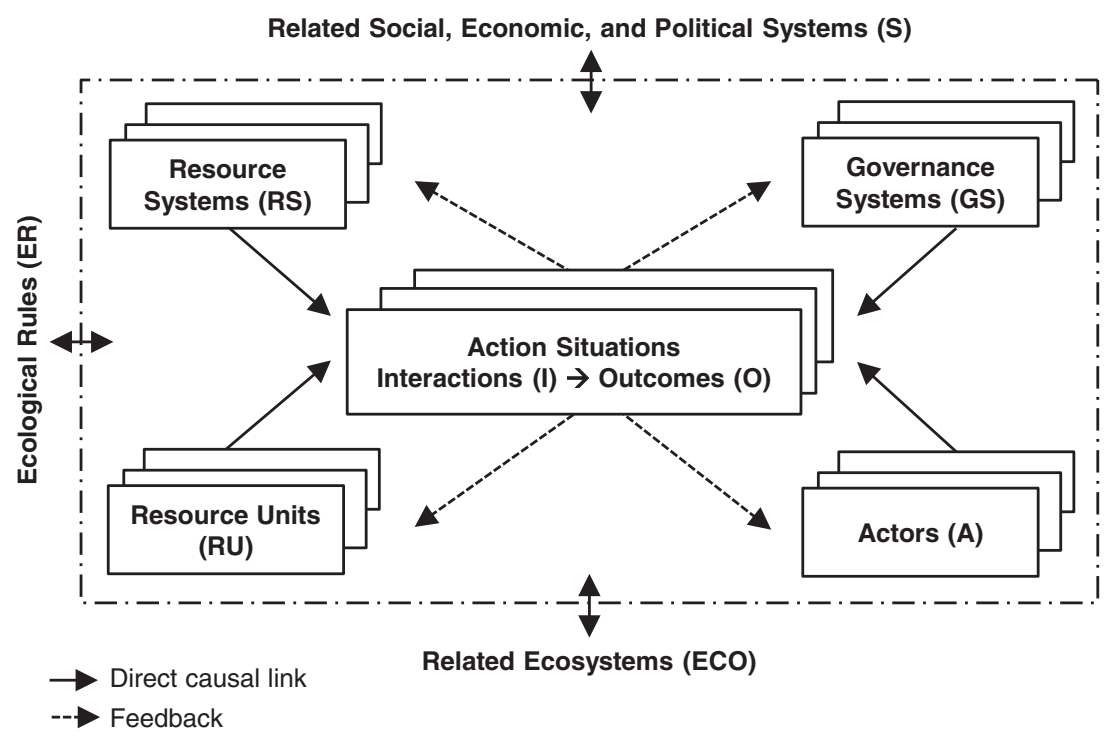

components. Four of these - resource systems (RS), resource units (RU), actors (A), and governance systems (GS) - are defined by sets of attributes (Table 1) that jointly shape interrelated processes of interaction (I), leading to observed and evaluated outcomes $(\mathrm{O})$. Resource units, as an example, are defined by seven attributes, including: the rate at which harvested units are replaced (RU2), their economic value (RU4), and level of mobility (RU1). Each of these attributes has an impact on the information and incentives that actors face when making decisions in the social-ecological system. For instance, the likelihood that resource users will invest in activities to manage a resource is expected to form an inverted curvilinear relation with the replacement rate of that resource (Basurto and Ostrom, 2009). At very slow replacement rates, gains in the distant future are likely to be heavily discounted, generating few positive incentives for collective action, while rapid replacement obviates the need for collective action over a given range of demand. ${ }^{3}$ Thus, collective action to manage a resource is most likely to occur in the context of resources with intermediate replacement rates.

A key feature of the framework is its explicit recognition that the effects of any attribute of a system may be mediated by other attributes of that system, most notably institutions that jointly influence the incentives of actors (Agrawal and Yadama, 1997; Poteete and Ostrom, 2004). In other words, although we expect

3 If resource replacement rates are slow enough, and returns from current exploitation are high enough, even private owners of resources can be expected to unsustainably overexploit those resources (see Clark, 1973a, 1973b). 
Table 1. Tier-one components of the SES framework based on Ostrom (2007)

\begin{tabular}{|c|c|c|c|c|c|c|}
\hline Resource systems & Resource units & Governance systems & Actors & Interactions & Outcomes & $\begin{array}{l}\text { Related } \\
\text { ecosystems }\end{array}$ \\
\hline $\begin{array}{l}\text { RS1 Sector } \\
\text { RS2 Boundary clarity } \\
\text { RS3 Size } \\
\text { RS4 Infrastructure } \\
\text { RS5 Productivity } \\
\text { RS6 Equilibrium } \\
\quad \text { properties } \\
\text { RS7 Predictability } \\
\text { RS8 Storage capacity } \\
\text { RS9 Location }\end{array}$ & $\begin{array}{l}\text { RU1 Mobility } \\
\text { RU2 Replacement rate } \\
\text { RU3 Interactions } \\
\text { RU4 Economic value } \\
\text { RU5 Size } \\
\text { RU6 Distinctive } \\
\quad \text { markings } \\
\text { RU7 Distribution }\end{array}$ & $\begin{array}{l}\text { GS1 Government } \\
\text { organizations } \\
\text { GS2 Non-government } \\
\text { organizations } \\
\text { GS3 Network structure } \\
\text { GS4 Property rights } \\
\text { GS5 Operational rules } \\
\text { GS6 Collective-choice rules } \\
\text { GS7 Constitutional rules } \\
\text { GS8 Monitoring and } \\
\text { sanctioning processes }\end{array}$ & $\begin{array}{l}\text { A1 Group size } \\
\text { A2 Socioeconomic } \\
\text { attributes } \\
\text { A3 History of use } \\
\text { A4 Location } \\
\text { A5 Leadership } \\
\text { A6 Norms/social capital } \\
\text { A7 Knowledge of SES } \\
\text { A8 Resource dependence } \\
\text { A9 Technology used }\end{array}$ & $\begin{array}{l}\text { I1 Harvesting } \\
\text { levels } \\
\text { I2 Information } \\
\text { sharing } \\
\text { I3 Deliberation } \\
\text { processes } \\
\text { I4 User conflicts } \\
\text { I5 Investment } \\
\text { activities } \\
\text { I6 Lobbying } \\
\text { activities }\end{array}$ & $\begin{array}{l}\text { O1 Social } \\
\text { preference } \\
\text { measures } \\
\text { O2 Ecological } \\
\text { performance } \\
\text { measures } \\
\text { O3 Externalities } \\
\text { to other SESs }\end{array}$ & $\begin{array}{l}\text { RE1 Climate } \\
\text { patterns } \\
\text { RE2 Pollution } \\
\text { patterns } \\
\text { RE3 Flows } \\
\text { into and } \\
\text { out of focal } \\
\text { SES }\end{array}$ \\
\hline
\end{tabular}


intermediate rates of replacement to enhance prospects for collective action, a diverse assortment of relationships may be observed, as factors such as resource mobility (RU1), group size (A1), and property rights (GS4) vary across socialecological systems. A thorough diagnosis depends upon an enumeration of the relevant attributes of a social-ecological system that are sufficient to account for behavior and outcomes in that system. Given the complexity involved, the SES framework is designed to allow scholars to leverage knowledge from prior research across relevant disciplines, specifically by focusing their attention on a smaller subset of discrete and easily coded attributes related to a particular question or method of inquiry. In this way, knowledge accumulates piecewise through iterative processes of hypothesis generation, testing, and refinement toward a more general theory of sustainability. The danger, however, is that in focusing only on a small subset of variables, scholars will neglect interactions among institutions that generate substantially different outcomes. Ironically, Ostrom's (2007) own analysis of Hardin's Herder Problem illustrates this very problem.

\section{Ostrom's application of the SES framework to Hardin's Herder Problem}

Ostrom (2007) sought to demonstrate the diagnostic utility of the SES framework by applying it to Hardin's (1968) 'tragedy of the commons'. In Hardin's description, ${ }^{4}$ herders on an open-access pasture lacked incentives to conserve that pasture by controlling the number of cattle grazing upon it. Market incentives guided them (as if by an 'invisible hand') to keep adding more and more cattle to their herds to maximize private profits, even though doing so reduced the social product, as the pasture deteriorated. Hardin (1968) believed the only way to avoid destruction of the open-access pasture was to either privatize the pasture or for governments to regulate access and use. Ostrom (1990) successfully rebutted Hardin's presumption that common-property solutions - self-regulation by the herders themselves - would be ineffective. But she did not question his presumption that property rights in the pasture were the focal institutions.

Ostrom (2007) depicted the situation, using the SES framework, as shown in Figure 2. This figure demonstrates the utility of the SES framework by showing how Hardin's (1968) entire textual analysis can be condensed to a few relatively simple variables and presented in an easy-to-understand graphical fashion. And it shows how individual case studies - stylized and real, thickly or thinly descriptive - might be diagnosed and compared using regularized variables. But, most importantly, it shows that incomplete attention to the set of institutions affecting social-ecological outcomes can lead to inappropriate diagnosis and analysis.

4 Earlier versions had been told by Aristotle $(1941, \$ 1262$ b34-35) in the fourth century BCE, and fisheries economists writing in the twentieth century CE, including Andersen (1983), Gordon (1954), and Scott (1955). 
Figure 2. Ostrom's SES diagnosis of the Herder Problem.

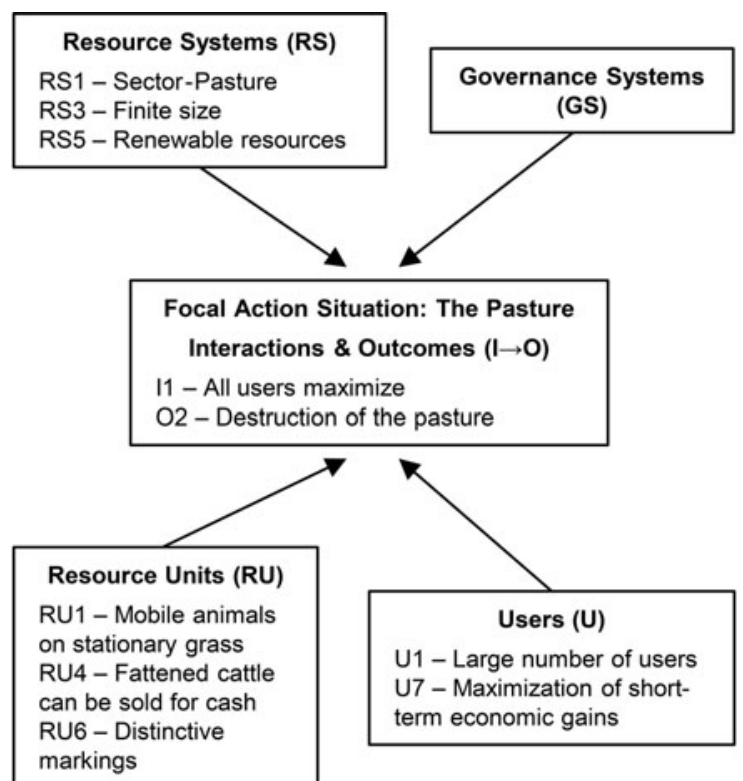

The most striking feature of Ostrom's (2007) treatment of Hardin's Herder Problem is the complete absence of Governance System variables, as if the entire situation is pre- or non-institutional. This might be an accurate reflection of Hardin's own understanding of the situation, but it is misleading. As a conceptual matter, what could it mean for any social system, as such, to be pre-institutional, that is, devoid of rules, norms, customs, or habits? Simply put, a social system without an institutional structure is not a social system.

It is doubtful that Ostrom actually believed such a null set of institutions was a practical possibility, although elsewhere (e.g., Ostrom, 1990: 2-3, 140) she does invoke a Hobbesian state of nature (see Hobbes, [1651] 1994) to describe the 'tragedy of the commons' and the default conditions under which humans interact over common-pool resources. ${ }^{5}$ Even if Ostrom (1990) did not intend the state of nature to be taken literally as a description of very early

5 The phrase 'common-pool resource' refers to a particular set of goods that are rivalrous in consumption but from which exclusion is very costly. These are distinguished from private goods (easy excludability and rivalrous in consumption), public goods (very costly to exclude but non-rivalrous in consumption), and toll goods (low-cost excludability and rivalrous in consumption) (V. Ostrom and E. Ostrom, 1977: 12, Fig. 1). These types of goods, with their varying characteristics, must not be confused with the various property systems (private, common, public, or hybrid) that might be deployed to manage them. Unfortunately, scholars still sometimes confuse or conflate common-pool resources with property systems used to manage them. For a recent example, see Araral (2014: 19), observing a 'fundamental difference between CPR (the acronym he uses to denote common-pool resources) and private property'. A common-pool resource system can be managed either via private property, common property, or public property, or admixtures of the three (see, e.g., Cole, 2002; Cole and Ostrom, 2012). 
human society, the complete absence of Governance System variables reflects a Hobbesian interpretation in which no humanly devised institution has any relevance (i.e., would affect outcomes) in that setting.

Hardin (1968) did, of course, recommend the imposition of institutional arrangements associated with either markets and private property or governments and regulation to avoid the open-access tragedy. So it is not entirely fair to accuse Hardin of being unaware of the importance of institutions. A more reasonable criticism is that Hardin failed to realize just how institution-laden his allegoric setting already was, prior to the imposition of any institutional solution. Ostrom's (1990) research unequivocally demonstrated that Hardin overlooked viable institutional solutions, specifically common-property regimes that satisfy the design principles she identified. ${ }^{6}$ We take Ostrom's primary point in this exercise to be a plausible explanation for why Hardin was unable to see other paths that might avert the tragedy by introducing other kinds of institutions.

The specific mode of argument used by Ostrom (2007) to make this point, however, may have a similarly narrowing effect on future analysts. By presuming that institutions were completely absent from Hardin's pasture (or, that it was pre-institutional), Ostrom was drawn to suggest the addition of new institutions, rather than investigating ways in which existing but unrecognized institutions contributed to that tragedy in the first place, or how the continued presence of existing institutions might undermine efforts to avert the tragedy by building new ones.

In fact, a null set of institutions is inconsistent with the 'tragic' outcome that Hardin described and Ostrom indicates as Outcome (O2) in her SES analysis. In the absence of formal or informal institutions protecting ownership (or possession) of cattle, herders have little if any incentive to let loose their cattle on the open-access pasture, where others might claim them. Opportunities to profit from selling cattle would be limited by the absence of institutions that (1) recognize and protect ownership and (2) enforce impersonal contracts (see, e.g., Greif, 2005; North, 1990). Consequently, trade would be greatly restricted, and the pasture would not likely be overgrazed. The 'tragedy of the commons' would not arise. ${ }^{7}$

Ostrom (2007: 15183) observed that 'the animals ... grazing on the pasture are the property of their owners', who receive 'all the proceeds from the sale'

6 Ostrom's (1990: 90, Table 3.1) eight design principles are: (1) clearly defined boundaries, (2) congruence between appropriation and provision rules and local conditions, (3) most affected individuals participate in rule-making, (4) reliable monitoring, (5) graduated sanctions, (6) rapid and low-cost conflictresolution mechanisms, (7) minimal recognition and acceptance of local rules by external authorities, and (8) local rules nested in larger governance systems (for common-property regimes that are part of larger systems).

7 A tragedy of the commons could arise from mere subsistence use if the number of users is large enough relative to the size of the pasture, and their demand outstrips the replacement rate of the grass. But such a scenario is far less likely, and it is not the scenario that Hardin portrayed in his seminal paper. 
of any cattle they have grazed on the open-access pasture. But, surprisingly, her application of the SES framework did not incorporate these social facts. Not only are they inconsistent with her empty Governance Systems box, they are central to Hardin's story. The overexploitation of the pasture results directly from the incentives created by the combination of the following institutional elements: (1) no property rights in the pasture land; (2) private ownership of cattle, including the right to alienate and the right to all proceeds from alienation; (3) an implicit rule that grass is, in effect, privatized to the herder as it is consumed and metabolized by that herder's cattle; ${ }^{8}$ and (4) incentives stemming from the structure of market institutions. Each of these institutional variables is a matter of collective choice, which is to say, they could be otherwise. If one or more of these were altered, Hardin's tragedy might not have resulted in the first place.

\section{A revised application of the SES framework to Hardin's Herder Problem}

Figure 3 revises Ostrom's (2007) depiction of the tragedy to incorporate institutional attributes of the social-ecological system that are needed to specify conditions for the deterioration of an open-access pasture. Some of these changes, most notably the explicit division between grass and cattle, are simply a matter of reorganization to clarify their role as discrete components of the social-ecological system. Others are novel. For example, the existence of an exogenous supply of cattle is not mentioned in either account, but presumably the cattle have some external origin, given that herders seem to collectively possess a large enough supply of cattle to deplete the pasture. Herders presumably also have access to alternative sources of feed upon which the cattle could be fattened for sale. The most important changes, in the Governance Systems component, signify that the tragedy of the open-access pasture is the product of interactions among institutions that assign individual rights over the cattle that convert unowned grass from the open-access pasture into privately owned beef.

Using the Roman law distinctions that continue to dominate modern theories of property (Birks and McLeod, 1987; Cole, 2002: 8-14; Cole and Ostrom, 2012: 44-45), ${ }^{9}$ the pasture (i.e., the land itself) is res communes omnium (the common property of all), ${ }^{10}$ which means that no one can exclude anyone else from entry

8 The 'tragedy of the commons' story is not restricted to this combination of privately owned cattle and open-access pastureland. What is critical is that part of a publicly available resource can be captured and used, either directly or indirectly, for private gain. An analogous tragedy might occur in the absence of clearly defined property rights, but analysis of that case would have to incorporate transaction costs of capturing and protecting private gains.

9 We do not mean to suggest that the set of institutions conditioning access to and use of Hardin's pasture is determined by Roman law or, indeed, any formal legal system. However, Roman law property categories provide a convenient set of concepts for understanding the institutional structure of both formal and informal legal systems.

10 The Roman property category of res communes implied an unchangeable non-property status that is very different from modern conceptions of the phrase 'common property', which imply group, 
Figure 3. Revised application of the SES framework to the Herder Problem.

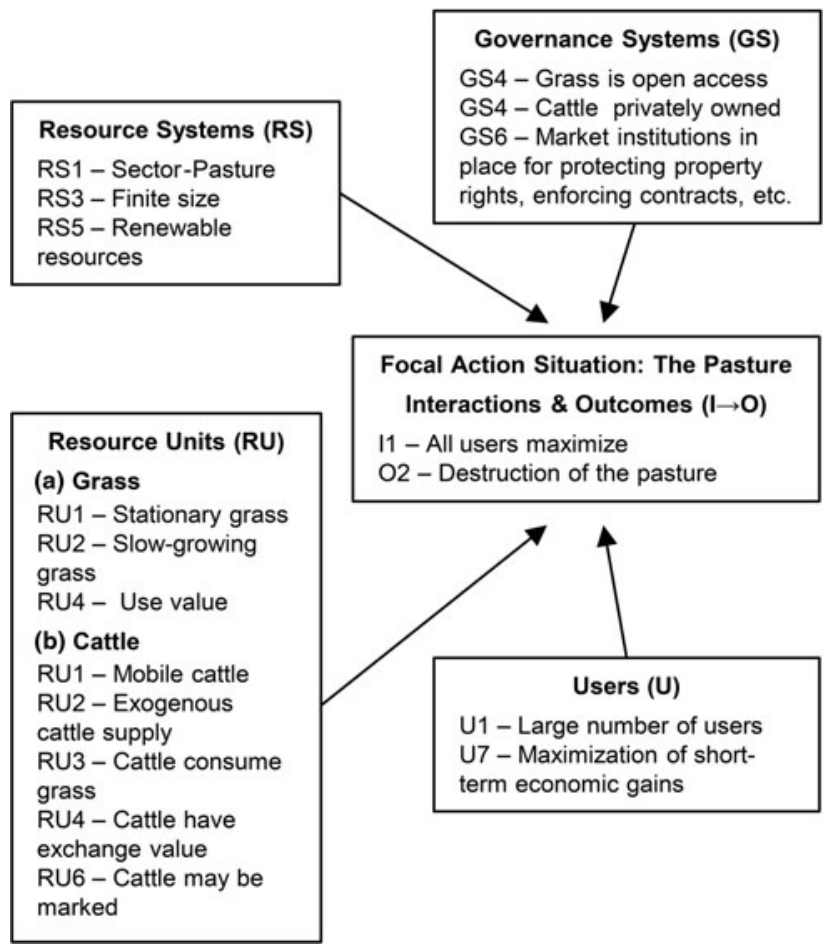

and use, but neither does entry and use (e.g., acts of occupation or possession) create rights of ownership (which would signify res nullius or non-property) in the pasture lands. The grass growing on the pasture is not res communes but res nullius, an unowned resource available for appropriation as private property (res privatce) by acts of extraction or consumption. Conversion from non-property to property occurs via the 'rule of capture', which applies to many 'wild' natural resources, including not only wild animals and fish but also groundwater, oil, and gas, and in this case, unowned grass on the open-access pasture (see, e.g., Johnston, 2005). The cattle that graze on the grass are res privatce, owned by the herders who release them onto the pasture to feed. Because the cattle are domesticated animals, they remain private property even after they leave the land of their owners; they do not become open for recapture by others following their release onto the commons (see, e.g., Ingham, 1900). While on the pasture, the cattle serve, in effect, as agents of the herders, converting the grass from

communal, or collective ownership. Today, as Araral (2014: 19) observes, 'common property' can denote a special form of private property; that is, property owned by more than a single individual. However, other modern forms of common property, such as tribal property or communes, appear more like public than private property (see, e.g., Cole and Ostrom, 2012: 44, Fig. 2.1). 
open-access to private property simply by consuming it. We know this by virtue of the fact that the value of the added weight of each cow, attributable to grass consumed from the pasture, belongs entirely to that cow's owner when the cow is sold in market.

These various property rules, as applied to the pasture, the grass, the cattle, and their owners, are a fortiori institutions. They are not socially immutable 'brute facts' about the world but inherently alterable 'institutional facts' (see Searle, 1995). They belong to the Governance Systems box because they all play a significant role in driving behavior in and outcomes of Hardin's Herder Problem. Changing one or more of these property rules could easily alter the outcome because the ecological components of a system are inextricably linked via a variety of natural processes (Araral, 2013; Holling and Meffe, 1996). Imagine, for example, if the law treated domesticated animals just as it does wild animals so that any cow released (or escaping) onto the open-access pasture would become res nullius (just like the grass) and liable to recapture by anyone (see Arnold, 1921; Ingham, 1990). How likely would a herder be to release the first, let alone the next (or the $n$ th), cow onto the pasture? The pasture would more likely be underutilized than overexploited. Or, what if the grass were not res nullius but res communes so that even after consumption by a herder's cow, all members of the community would have a right to share in the increased market value of that cow attributable to the amount of grass it consumed from the common pasture? Measurement problems would arise, but such a rule would also alter the incentives for overgrazing, as much as if the pasture itself was privatized. ${ }^{11}$

This is not to argue that any of the several property rules at work on Hardin's pasture should be different than it is - the analysis here is positive, not normative. There may be excellent socioeconomic reasons supporting the existing set of institutions, even if those choices in the aggregate contribute to potential commons tragedies.

Other background institutions play an integral role in Hardin's allegory. For one, private property rights (and correlative duties) in the cattle require enforcement mechanisms. In addition, Hardin presumes the existence of functional markets for cattle-based products, and such markets require money (or barter) and contracts plus contract-enforcement mechanisms. In the absence

11 Such a sharing rule is not fanciful. Rechlin et al. (2002), for example, discuss community forest systems in China and Nepal that require sharing of monetary and material benefits from forest harvests with all stakeholders. Somewhat closer to the present context, the great French novelist Victor Hugo, in his masterpiece Les Misérables ([1862] 1887: 75-76), discusses mid-mountain peasants who share the proceeds of the cattle they graze to produce cheese. In other cultures, a number of herders may own various shares of cows grazed on a common pasture (see Mors, 1954). This is not to argue normatively for such a solution to a potential commons tragedy. We are merely making an analytical point about variability of property institutions. 
of institutions supporting market exchange, herders would graze cattle only for their use value, thereby reducing pressure on the pasture. ${ }^{12}$

Some resource systems and institutions left out of Hardin's allegory entirely, as well as Ostrom's application to it of the SES framework, can play a major role in determining social and ecological outcomes. To take only one example, cattle do not live by grass alone but also require water (Ensminger and Rutten, 1991: 688). Where is the water on or near Hardin's pasture? And what rules or norms govern its use? Without answers to these questions, any SES analysis of Hardin's 'tragedy of the commons' must remain incomplete. It is, however, a virtual certainty that without some reliable water source for the cattle, the pasture would not be overgrazed.

\section{Institutional interactions and institutional fit}

This paper has shown that a myopic preoccupation with a single institutional variable applied to a single resource system (property rights in the pasture) while neglecting related and interacting resources (the grass and the cattle), and the institutions that condition human interactions with those resources, can result in impoverished analyses and misdiagnoses. If the Governance System in Hardin's Herder Problem were truly a null set, as both Ostrom (2007) and Hardin (1968) treated it, the 'tragedy of the commons' would not have arisen. In an institutional vacuum, atomistic herders would lack incentives to graze more cows than they could physically protect from misappropriation.

Conceptually, the notion of a pre- or non-institutional social system is a contradiction in terms. Empirically, the world we inhabit is replete with institutions that prescribe what actions must, must not, or may be taken given certain conditions (Coleman, 1987; Crawford and Ostrom, 1995; Elster, 2007). While some institutions, notably reciprocity norms, enable groups to solve a diverse assortment of social dilemmas (Axelrod, 1984; Fehr et al., 2002; Ostrom, 1998, 2009), others constrain, limit, or undermine cooperation, equality, and collective well-being (North, 1990). Any system of institutional arrangements is, as a consequence, deeply complex.

Our analysis also has implications for the notion of 'institutional fit', which suggests that institutions ought to fit or match the defining features of the problems they are meant to address (Folke et al., 2007; Young, 2002, 2008). This paper demonstrates that institutional fitness is not just a matter of relations between discrete institutions and ecological circumstances but also concerns how various institutions (and sets of institutions) affecting resources interact

12 On the distinction between 'use value' and 'exchange value', see, for example, Smith ([1776] 1994: 31). Note the implication that whether a commodity possesses exchange value or only use value depends substantially on the institutional setting and not simply on its scarcity (available supply relative to demand). 
with each other. Simply put, institutional fit is about both (1) how the rules fit the biophysical conditions and (2) how the rules fit with other rules. In fact, some have argued that Ostrom's (1990) successful common-property regimes are better understood as a special case of collective private property that depend upon interactions between shared appropriation and management rights within a group, and the ability to apply those rights to exclude other groups (Araral, 2014). ${ }^{13}$ Moreover, viewed in isolation, the absence of a property regime governing access to and use of a pasture cannot lead to any predictions about the level of use. Indeed, as Libecap (1989: 13-14) has explained, open-access may be economically optimal in conditions where supply is high and demand is low so that the costs of introducing and enforcing property rights and duties (among other institutions) would outweigh the benefits. Open-access is, in fact, the default condition in the absence of institutions (including social norms) created through collective action.

Institutional studies of commons and social-ecological systems often support an optimistic view regarding the potential for institutional change to lead to sustainable and equitable use of natural resources across diverse human societies. But sustainability is not merely a question of finding the best institution for a given environmental problem. Rather, multiple, interacting institutions in complex social-ecological systems generate incentives that can either support or degrade resource sustainability, among other social goals.

No single analysis can detail all the institutional arrangements that might conceivably affect outcomes in a complex social-ecological system, but analysts must work hard to avoid overlooking especially important institutional factors. Ostrom (2007: 15181) intended the SES framework to be 'a step toward building a strong interdisciplinary science of complex, multilevel systems that will enable future diagnosticians to match governance arrangements to specific problems embedded in a social-ecological context'. Ironically, she stopped short in her own SES-based analysis of Hardin's allegory of the 'tragedy of the commons', but this paper demonstrates the power of the SES framework to point out such mistakes and suggest further improvements in our collective understanding.

The 'tragedy of the commons' is not a consequence of the absence of institutions but instead a set of maladapted institutions that support incentives for overexploitation. The appropriate response is not necessarily to create new institutions; an alteration in existing institutional arrangements may sometimes be sufficient. Even when new institutions seem desirable, they must be analyzed within the context of the existing set of institutions with which they must interact.

The open-access pasture does not exist in splendid isolation but operates within a larger universe of interacting resources and institutions. Hardin's

13 But see note 10 above, observing that common-property regimes may closely resemble either group private ownership or certain forms of public ownership. 
'tragedy of the commons' is not just about the pasture; it is equally about the grass, the cows, the herders, and the human society.

\section{Acknowledgements}

We thank Marty Anderies, Marco Janssen, Patty Lezotte, Arden Rowell, and presentation audiences at the Ostrom Workshop at Indiana University Bloomington, the Center for the Study of Institutional Diversity at Arizona State University, and the Midwest Law \& Economics Association annual meeting at the University of Illinois College of Law. Financial support for Professor Cole's participation in this project was provided by a FORMAS grant from the Swedish Research Council for the joint research program, COMMONS.

\section{References}

Acheson, J. M. (2006), 'Institutional Failure in Resource Management', Annual Review of Anthropology, 35(1): 117-134.

Agrawal, A. and G. Yadama (1997), 'How Do Local Institutions Mediate Market and Population Pressures on Resources? Forest Panchayats in Kumaon, India', Development and Change, 28(3): 435-465.

Andersen, P. (trans) (1983), 'On Rent of Fishing Grounds: A Translation of Jens Warming's 1911 Article, with an Introduction', History of Political Economy, 15(3): 391-396.

Araral, E. (2013), 'What Makes Socio-Ecological Systems Robust? An Institutional Analysis of the 2,000 Year-Old Ifugao Society', Human Ecology, 41(6): 859-870.

Araral, E. (2014), 'Ostrom, Hardin and the Commons: A Critical Appreciation and a Revisionist View’, Environmental Science \& Policy, 36: 11-23.

Aristotle (1941), The Basic Works of Aristotle, R. McKeon (ed. and trans.), New York, NY: Random House, pp. 1127-1324.

Arnold, E. C. (1921), 'The Law of Possession Governing the Acquisition of Animals Ferae Naturae', American Law Review, 55(3): 393-404.

Axelrod, R. (1984), The Evolution of Cooperation, New York, NY: Basic Books.

Baland, J.-M. and J.-P. Platteau (1996), Halting Degradation of Natural Resources, Oxford, UK: Oxford University Press.

Ban, N. C., M. Mills, J. Tam, C. C. Hicks, S. Klain, N. Stoeckl, M. C. Bottrill, J. Levine, R. L. Pressey, T. Satterfield, and K. M. A. Chan (2013), 'A Social-Ecological Approach to Conservation Planning: Embedding Social Considerations', Frontiers in Ecology and the Environment, 11(4): 194-202.

Basurto, X. and E. Ostrom (2009), 'Beyond the Tragedy of the Commons', Economia delle fonti di energia e dell'ambiente, 52(1): 35-60.

Birks, P. and G. McLeod (trans.) (1987), Justinian's Institutes, Ithaca, NY: Cornell University Press.

Blanco, E. (2011), 'A Social-Ecological Approach to Voluntary Environmental Initiatives: The Case of Nature-Based Tourism', Policy Sciences, 44(1): 35-52.

Brook, B. W., N. S. Sodhi, and P. K. L. Ng (2003), 'Catastrophic Extinctions Follow Deforestation in Singapore', Nature, 424(6947): 420-426. 
Chhatre, A. and A. Agrawal (2009), 'Trade-Offs and Synergies Between Carbon Storage and Livelihood Benefits from Forest Commons', Proceedings of the National Academy of Sciences USA, 106(42): 17667-17670.

Cinner, J. E., T. R. McClanahan, M. A. MacNeil, N. A. J. Graham, T. M. Daw, Ahmad, Mukminin, D. A. Feary, et al. (2012), 'Comanagement of Coral Reef Social-Ecological Systems', Proceedings of the National Academy of Sciences USA, 109(14): 5219-5222.

Clark, C. W. (1973a), 'The Economics of Overexploitation', Science, 181: 630-634.

Clark, C. W. (1973b), 'Profit Maximization and the Extinction of Animal Species', Journal of Political Economy, 81(4): 950-961.

Clement, F. (2010), 'Analysing Decentralised Natural Resource Governance: Proposition for a "Politicised" Institutional Analysis and Development Framework', Policy Sciences, 43(2): 129-156.

Cole, D. H. (2002), Pollution and Property: Comparing Ownership Institutions for Environmental Protection, Cambridge, MA: Cambridge University Press.

Cole, D. H. and P. Z. Grossman (2010), 'Institutions Matter! Why the Herder Problem is not a Prisoner's Dilemma', Theory and Decision, 69(2): 219-231.

Cole, D. H. and E. Ostrom (2012), 'The Variety of Property Systems and Rights in Natural Resources', in D. H. Cole and E. Ostrom (eds.), Property in Land and Other Resources, Cambridge, MA: Lincoln Institute of Land Policy, pp. 37-64.

Coleman, J. S. (1987), 'Norms as Social Capital', in G. Radnitzky and P. Bernholz (eds.), Economic Imperialism: The Economic Approach Applied Outside the Field of Economics, New York, NY: Paragon House, pp. 133-155.

Cox, M., G. Arnold, and S. Villamayor Tomas (2010), 'A Review of Design Principles for Community-Based Natural Resource Management', Ecology and Society, 15(4): 38.

Crawford, S. E. S. and E. Ostrom (1995), 'A Grammar of Institutions', American Political Science Review, 89(3): 582-600.

Edmondson, W. T., G. C. Anderson, and D. R. Peterson (1956), 'Artificial Eutrophication of Lake Washington', Limnology and Oceanography, 1(1): 47-53.

Elster, J. (2007), Explaining Social Behavior: More Nuts and Bolts for the Social Sciences, Cambridge, UK: Cambridge University Press.

Ensminger, J. and A. Rutten (1991), 'The Political Economy of Changing Property Rights: Dismantling a Pastoral Commons', American Ethnologist, 18(4): 683-699.

Epstein, G., J. M. Vogt, S. K. Mincey, M. Cox, and B. Fischer (2013), 'Missing Ecology: Integrating Ecological Perspectives with the Social-Ecological System Framework', International Journal of the Commons, 7(2): 432-453.

Feeny, D., F. Berkes, B. J. McCay, and J. M. Acheson (1990), 'The Tragedy of the Commons: Twenty-Two Years Later', Human Ecology, 18(1): 1-19.

Fehr, E., U. Fischbacher, and S. Gächter (2002), 'Strong Reciprocity, Human Cooperation, and the Enforcement of Social Norms', Human Nature, 13(1): 1-25.

Fleischman, F., K. Boenning, G. Garcia-Lopez, S. Mincey, M. Schmitt-Harsh, K. Daedlow, M. C. Lopez, X. Basurto, B. Fischer, and E. Ostrom (2010), 'Disturbance, Response, and Persistence in Self-Organized Forested Communities: Analysis of Robustness and Resilience in Five Communities in Southern Indiana', Ecology and Society, 15(4): 9.

Folke, C., L. Pritchard, F. Berkes, J. Colding, and U. Svedin (2007), 'The Problem of Fit Between Ecosystems and Institutions: Ten Years Later', Ecology and Society, 12(1): 30 .

Gordon, H. S. (1954), 'The Economic Theory of a Common-Property Resource: The Fishery', Journal of Political Economy, 62(2): 124. 
Greif, A. (2005), 'Commitment, Coercion, and Markets: The Nature and Dynamics of Institutions Supporting Exchange', in C. Ménard and M. Shirley (eds.), Handbook of New Institutional Economics, Amsterdam, Netherlands: Springer, pp. 727-786.

Gutiérrez, N. L., R. Hilborn, and O. Defeo (2011), 'Leadership, Social Capital and Incentives Promote Successful Fisheries', Nature, 470(7334): 386-389.

Hardin, G. (1968), 'The Tragedy of the Commons', Science, 162(3859): 1243-1248.

Hobbes, T. ([1651] 1994), Leviathan, Cambridge, MA: Hackett.

Holling, C. S. and G. K. Meffe (1996), 'Command and Control and the Pathology of Natural Resource Management', Conservation Biology, 10(2): 328-337.

Hugo, V. ([1862] 1887), The Works of Victor Hugo, I. F. Hapgood (trans.), New York, NY: Thomas Y. Crowell.

Ingham, J. H. (1900), Law of Animals: A Treatise on Property in Animals: Wild and Domestic and the Rights and Responsibilities Arising Therefrom, Philadelphia, PA: T \& J Johnson.

Johnston, J. S. (2005), 'The Rule of Capture and the Economic Dynamics of Natural Resource Use and Survival Under Open Access Management Regimes', Environmental Law, 35(4): 855-898.

Larson, A. M. and F. Soto (2008), 'Decentralization of Natural Resource Governance Regimes', Annual Review of Environment and Resources, 33(1): 213-239.

Libecap, G. D. (1989), Contracting for Property Rights, Cambridge, UK: Cambridge University Press.

Ludwig, D., R. Hilborn, and C. Waters (1993), 'Uncertainty, Resource Exploitation and Conservation: Lessons from History', Science, 260(5104): 17-36.

Mors, P. O. (1954), 'Cattle in Buhaya', Anthropology Quarterly, 27(1): 23-29.

Myers, R. A., J. A. Hutchings, and N. J. Barrowman (1997), 'Why Do Fish Stocks Collapse? The Example of Cod in Atlantic Canada', Ecological Applications, 7(1): 91-106.

North, D. C. (1990), Institutions, Institutional Change and Economic Performance, Cambridge, UK: Cambridge University Press.

Ostrom, E. (1990), Governing the Commons: The Evolution of Institutions for Collective Action, New York, NY: Cambridge University Press.

Ostrom, E. (1998), 'A Behavioral Approach to the Rational Choice Theory of Collective Action', American Political Science Review, 92(1): 1-22.

Ostrom, E. (2007), 'A Diagnostic Approach for Going Beyond Panaceas', Proceedings of the National Academy of Sciences USA, 104(39): 15181-15187.

Ostrom, E. (2009), 'A General Framework for Analyzing Sustainability of Social-Ecological Systems', Science, 325(5939): 419-422.

Ostrom, E. and M. Cox (2010), 'Moving Beyond Panaceas: A Multi-Tiered Diagnostic Approach for Social-Ecological Analysis', Environmental Conservation, 37(4): 451463.

Ostrom, V. (2008), The Intellectual Crisis in American Public Administration, 3rd edn, Tuscaloosa, AL: University of Alabama Press.

Ostrom, V. and E. Ostrom (1997), 'Public Goods and Public Choices', in E. S. Savas (ed.), Alternatives for Delivering Public Services: Toward Improved Performance, Boulder, CO: Westview Press, pp. 7-49.

Pierson, P. (2000), 'Increasing Returns, Path Dependence, and the Study of Politics', American Political Science Review, 94(2): 251-267.

Poteete, A. R. and E. Ostrom (2004), 'Heterogeneity, Group Size and Collective Action: The Role of Institutions in Forest Management', Development and Change, 35(3): 435461. 
Rechlin, M. A., A. L. Hammett, W. R. Burch, and Y. Song (2002), 'Sharing the Wealth: A Comparative Study of the Distribution of Benefits from Community Forestry Management in Southern China and Nepal', Journal of Sustainable Forestry, 15(2): 1-23.

Ribot, J. C., A. Agrawal, and A. M. Larson (2006), 'Recentralizing While Decentralizing: How National Governments Reappropriate Forest Resources', World Development, 34(11): 1864-1886.

Scott, A. D. (1955), 'The Fishery: The Objectives of Sole Ownership', Journal of Political Economy, 63(2): 116-124.

Searle, J. R. (1995), The Construction of Social Reality, London: Penguin.

Simon, H. A. (1962), 'The Architecture of Complexity', Proceedings of the American Philosophical Society, 106(6): 467-482.

Smith, A. ([1776] 1994), An Inquiry into the Nature and Causes of the Wealth of Nations, New York, NY: Modern Library.

Wade, R. (1994), Village Republics, San Francisco, CA: ICS Press.

Young, O. R. (2002), The Institutional Dimensions of Environmental Change: Fit, Interplay, and Scale, Cambridge, MA: MIT Press.

Young, O. R. (2008), 'The Architecture of Global Environmental Governance: Bringing Science to Bear on Policy', Global Environmental Politics, 8(1): 14-32. 
Reproduced with permission of the copyright owner. Further reproduction prohibited without permission. 